\title{
Retrieval of aerosol single scattering albedo at ultraviolet wavelengths at the T1 site during MILAGRO
}

\author{
C. A. Corr ${ }^{1, *}$, N. Krotkov ${ }^{2}$, S. Madronich ${ }^{3}$, J. R. Slusser ${ }^{4}$, B. Holben ${ }^{5}$, W. Gao ${ }^{4}$, J. Flynn ${ }^{6}$, B. Lefer ${ }^{5}$, and \\ S. M. Kreidenweis ${ }^{1}$ \\ ${ }^{1}$ Department of Atmospheric Sciences, Colorado State University, Fort Collins, CO 80521, USA \\ ${ }^{2}$ Goddard Earth Sciences and Technology Center, University of Maryland, Baltimore County, MD 20771, USA \\ ${ }^{3}$ Atmospheric Chemistry Division, National Center for Atmospheric Research, Boulder, CO 80407, USA \\ ${ }^{4}$ The USDA UV-B Monitoring and Research Program, Natural Resource Ecology Laboratory, Colorado State University, \\ Fort Collins, CO 80521, USA \\ ${ }^{5}$ Biospheric Sciences Branch, NASA's Goddard Space Flight Center, Greenbelt, MD 20771, USA \\ ${ }^{6}$ Department of Earth and Atmospheric Sciences, University of Houston, 4800 Calhoun Rd, Houston, TX 77204-5007, USA \\ *now at: Complex Systems Research Center, Institute for the Study of Earth, Oceans, and Space, University of New \\ Hampshire, Durham, NH 03824, USA
}

Received: 8 January 2009 - Published in Atmos. Chem. Phys. Discuss.: 25 February 2009

Revised: 20 July 2009 - Accepted: 20 July 2009 - Published: 12 August 2009

\begin{abstract}
Surface measurements of direct and diffuse voltages at UV wavelengths were made at the $\mathrm{T} 1$ site during the MILAGRO (Megacity Initiative: Local and Global Research Observations) field campaign in March 2006, using a multifilter rotating shadowband radiometer (UV-MFRSR). We used the MFRSR data, together with measurements from a co-located CIMEL Sun photometer at the site operating as part of the AERONET network, to deduce aerosol single scattering albedo $(\omega)$ at 368 and $332 \mathrm{~nm}$ for four cloudfree days during the study. Our retrievals suggest that $\mathrm{T} 1$ aerosols with aerosol extinction optical depth $\tau_{368}>0.1$ that are influenced by Mexico City emissions, blowing dust, and biomass burning, are characterized by low $\omega_{368}=0.73-0.85$ and $\omega_{332}=0.70-0.86$, with small or no spectral variation of $\omega$ between 368 and $332 \mathrm{~nm}$. Our findings are consistent with other published estimates of $\omega$ for Mexico City aerosols, including those that suggest that the absorption attributable to these aerosols is enhanced at UV wavelengths relative to visible wavelengths. We also demonstrate, via sensitivity tests, the importance of accurate $\tau$ and surface albedo measurements in $\omega$ retrievals at $\mathrm{UV}$ wavelengths.
\end{abstract}

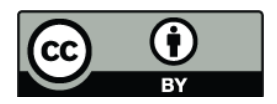

Correspondence to: C. A. Corr (ccorr@cisunix.unh.edu)

\section{Introduction}

Although ultraviolet (UV) radiation only comprises a small fraction $(<10 \%)$ of the total radiation reaching Earth's surface, and is therefore frequently ignored in climate modeling, it has profound impacts on human and ecosystem health. Prolonged exposure to UV-A $(315 \mathrm{~nm}<\lambda<400 \mathrm{~nm})$ and UV-B $(280 \mathrm{~nm}<\lambda<315 \mathrm{~nm})$ radiation has been shown to result in negative health effects such as sun burn (erythema), DNA damage, cataracts, and suppression of the immune systems in humans, and has been linked epidemiologically to skin cancer incidence (Diffey, 1991; Longstreth et al., 1998). Similarly, DNA damage in terrestrial plants has been found with exposure to UV radiation, ultimately resulting in adverse changes in plant growth and cell function (Bornman and Teramura, 1993). UV radiation is also the primary driver of photochemical processes in the troposphere. Atmospheric oxidant species (e.g., the hydroxyl radical $(\mathrm{OH})$, peroxy radicals $\left(\mathrm{H}_{2} \mathrm{O}_{2}, \mathrm{RO}_{2}\right)$ and chlorine radicals) are formed when precursor species undergo photolysis reactions, primarily in the UV range reaching the surface $(300 \mathrm{~nm}<\lambda<400 \mathrm{~nm})$. For example, nitrogen dioxide $\left(\mathrm{NO}_{2}\right)$ is efficiently photolyzed by UV-A radiation to form groundstate oxygen $\left(\mathrm{O}\left({ }^{3} \mathrm{P}\right)\right)$ which in the atmosphere rapidly reacts with $\mathrm{O}_{2}$ to form $\mathrm{O}_{3}$. Other molecules whose $\mathrm{UV}$ photolysis is important in the troposphere include $\mathrm{O}_{3}$, hydrogen peroxide $\left(\mathrm{H}_{2} \mathrm{O}_{2}\right)$, nitrous acid (HONO), formaldehyde $\left(\mathrm{CH}_{2} \mathrm{O}\right)$, and various other oxygenated organic compounds.

Published by Copernicus Publications on behalf of the European Geosciences Union. 
Modeling studies have suggested that scattering and absorption by aerosols can cause changes to the surface UV radiation field on the order of those caused by the thinning stratospheric ozone layer, but opposite in sign (Liu et al., 1991; Elminir, 2007; Reuder and Schwander, 1999; Krotkov et al., 1998). These aerosol perturbations to the UV radiation field can lead to substantial changes in tropospheric photolysis reactions and ozone photochemistry. These changes are complex and depend on altitude, chemical regime, and the relative extent of aerosol scattering or absorption. Highly absorbing aerosols tend to reduce photolytic radiation, particularly near the surface, while scattering aerosols can increase the radiation throughout the boundary layer and at higher altitudes above the bulk of the aerosol. The photochemical production of ozone depends on the square root of photolysis rates at low $\mathrm{NO}_{\mathrm{x}}$ and linearly at high $\mathrm{NO}_{\mathrm{x}}$ (e.g. Kleinman, 2005), so that the aerosol-induced UV perturbations have important implications for the production of urban and regional oxidants. Dickerson et al. (1997) showed that non-absorbing sulfate aerosols cause an increase in regional $\mathrm{O}_{3}$ in the Eastern US, by as much as $10-20 \mathrm{ppb}$, simply because they increase the UV radiation field. He and Carmichael (1999) also indicated that a moderate loading of scattering maritime and rural (remote) aerosol can increase photolysis rates by several percent, with concomitant increases in oxidant concentrations. On the other hand, Castro et al. (2001) showed that absorbing aerosols in Mexico City lead to a strong reduction in surface UV radiation, by $20-30 \%$ on two days of measurement in 1994, which implies a reduction of $\mathrm{O}_{3}$ formation by about $50 \mathrm{ppb}$.

Several parameters that describe the interaction between radiation and aerosols of particular interest to this work are single scattering albedo, aerosol optical depth, and asymmetry parameter. The single scattering albedo at a wavelength $\lambda$, $\omega_{\lambda}$, describes the contribution of particle scattering relative to total extinction by particles (absorption plus scattering):

$\omega_{\lambda}=\frac{b_{\text {sca, } \mathrm{p} \lambda}}{b_{\text {ext }, \mathrm{p} \lambda}}$

where $b_{\text {sca, }}$ is the aerosol scattering coefficient and $b_{\text {ext }, \mathrm{p}}$ is the sum of the aerosol scattering and absorption $\left(b_{\mathrm{abs}, \mathrm{p}}\right)$ coefficients:

$b_{\text {ext, } \mathrm{p}}=b_{\text {sca, } \mathrm{p}}+b_{\text {abs }, \mathrm{p}}$.

Aerosol optical depth $\left(\tau_{\lambda}\right)$ is the height-integrated extinction coefficient as computed from

$\tau_{\lambda}=\int_{z_{1}}^{z_{2}} b_{\mathrm{ext}, \mathrm{p} \lambda} d z$

where $z_{1}$ and $z_{2}$ represent the vertical bounds of an atmospheric layer. The total optical depth, $\tau_{\mathrm{TOT}, \lambda}$, includes contributions to extinction from gases as well as from particles. The asymmetry parameter, $g$, is the phase function-weighted average of the cosine of the scattering angle over all directions. Assuming azimuthal symmetry, the scattering angle integration extends from $-\pi$ to $+\pi$ :

$g=\frac{1}{2} \int_{-\pi}^{\pi} \cos \theta P(\theta) \sin \theta d \theta$

where $\theta$ is the scattering angle and $P(\theta)$ is the phase function. Values for $g$ range from -1 to 1 , with a value of -1 indicating incident radiation is backscattered and a value of 1 indicating forward scattering.

Several methods for the determination of aerosol optical properties in the visible spectral range using measurements of sun and sky radiances by Sun photometers and radiometers have been implemented. For example, Dubovik et al. (2002) demonstrated the retrieval of aerosol optical and microphysical properties using inversion techniques applied to observations of $\tau$ and the angular distribution of sky radiances at visible and near-infrared wavelengths, and Kassianov et al. (2005) proposed a method for retrieval of aerosol optical properties at visible wavelengths using measured direct and diffuse irradiances. Compared to the visible range, however, use of such methods for the determination of aerosol optical properties in the UV are more difficult, due to enhanced molecular (Rayleigh) scattering and interference from gaseous absorption $\left(\mathrm{NO}_{2}, \mathrm{O}_{3}, \mathrm{SO}_{2}\right)$ (Krotkov et al., 2005c). Additional challenges to the retrieval of $\omega$ at UV wavelengths include poorly-characterized surface albedos, which affect the sky radiances and irradiances, and stricter instrumental requirements, including small signal to noise ratio of measurements, stray light effects, filter stability, and wavelength calibration.

Despite these difficulties, several estimates of aerosol $\omega$ at UV wavelengths have been reported, as shown in Table 1 . The retrievals are based on fitting of measured direct and diffuse irradiances and their ratios (DDR) using a radiative transfer (RT) models with different a priori assumptions as indicated in Table 1. Assuming that aerosol optical depth, $\tau$, and the asymmetry factor, $g$, are known from co-located measurements, the direct $\omega$ retrieval is possible using single wavelength measurements as outlined in detail by Wenny et al. (1998) and Petters et al. (2003). Additional required RT model input parameters are ozone column, Rayleigh optical depth, and optical depth of absorbing gases including $\mathrm{NO}_{2}$, the ground albedo at the wavelength of interest $a_{\lambda}$, and solar zenith angle (SZA). Petters et al. (2003) assumed fixed values for all of these parameters except $\omega$, and iteratively determined the best-fit $\omega$ by varying $\omega$ in the radiative transfer model until the modeled DDR matched the measurements. Wenny et al. (1998) iterated on both $\omega$ and $g$, by adding a call to a Mie code to derive aerosol optical properties from a measured aerosol size distribution and an assumed real refractive index. The imaginary part of the refractive index was varied in the Mie extinction calculation until values of $g$ and $\omega$ were obtained that yielded modeled DDR in agreement with measurements. Krotkov et al. (2005a, b) applied 
Table 1. Published studies estimating $\omega$ at UV wavelengths, not including studies using in situ point measurements.

\begin{tabular}{|c|c|c|c|c|c|c|c|}
\hline & Method & Location/time & $\lambda$ & $\begin{array}{l}\text { Surface } \\
\text { albedo }[\lambda]\end{array}$ & $\tau[\lambda]$ & $g[\lambda]$ & $\omega[\lambda]$ \\
\hline Wenny et al. (1998) & $\begin{array}{l}\text { Modeling of measured } \\
\text { spectral response of UVB- } \\
1 \text { radiometer, } 280-320 \\
\text { broadband }\end{array}$ & $\begin{array}{l}\text { Western North } \\
\text { Carolina/Jun-Dec } \\
1995\end{array}$ & $312 \mathrm{~nm}$ & Not specified & $0.175-0.871^{\mathrm{d}}$ & $\begin{array}{l}0.63- \\
0.76^{\mathrm{g}}\end{array}$ & $\begin{array}{l}0.75- \\
0.93\end{array}$ \\
\hline $\begin{array}{l}\text { Hofzumahaus et } \\
\text { al. (2002) }\end{array}$ & $\begin{array}{l}\text { Best fit of modeled actinic } \\
\text { fluxes to measurements } \\
\text { from spectroradiometer }\end{array}$ & $\begin{array}{l}\text { Aegean Sea/Jun } \\
1996 \\
(2 \text { cases })\end{array}$ & $355 \mathrm{~nm}$ & $0.03^{\mathrm{a}}$ & Not specified ${ }^{\mathrm{e}}$ & $0.70^{\mathrm{a}}$ & $\begin{array}{l}0.87^{*} \\
\text { and } \\
0.95^{*}\end{array}$ \\
\hline Petters et al. (2003) & $\begin{array}{l}\text { Modeling of DDR from } \\
\text { UV-MFRSR }\end{array}$ & $\begin{array}{l}\text { Western North } \\
\text { Carolina/Jul-Dec } \\
1999\end{array}$ & $\begin{array}{l}300 \mathrm{~nm} \\
332 \mathrm{~nm} \\
368 \mathrm{~nm}\end{array}$ & $0.04^{\mathrm{b}}$ & Not specified $\mathrm{f}^{\mathrm{f}}$ & $0.70^{\mathrm{b}}$ & $\begin{array}{l}0.65- \\
0.91 \\
0.77- \\
0.97 \\
0.80- \\
0.99\end{array}$ \\
\hline Wetzel et al. (2003) & As in Petters et al. (2003) & $\begin{array}{l}\text { Poker Flat, } \\
\text { Alaska/Mar-Apr } \\
2001\end{array}$ & $368 \mathrm{~nm}$ & Variable $^{c}$ & Not specified ${ }^{\mathrm{f}}$ & $0.70^{\mathrm{b}}$ & $\begin{array}{l}0.63- \\
0.95\end{array}$ \\
\hline Goering et al. (2005) & $\begin{array}{l}\text { Modeling of DDR from } \\
\text { UV-MFRSR }\end{array}$ & $\begin{array}{l}\text { Mexico City } \\
\text { (MCMA), April } \\
2003 \\
14 \text { April } 2003 \text { (re- } \\
\text { ported in Barnard } \\
\text { et al., 2008) }\end{array}$ & $\begin{array}{l}332 \mathrm{~nm} \\
368 \mathrm{~nm}\end{array}$ & Not specified & Not specified ${ }^{\mathrm{f}}$ & $\begin{array}{l}\text { Not } \\
\text { speci- } \\
\text { fied }\end{array}$ & $\begin{array}{l}0.68- \\
0.94 \\
0.7- \\
0.95 \pm 0.03\end{array}$ \\
\hline Krotkov et al. (2005b) & $\begin{array}{l}\text { Modeling of DDR from } \\
\text { UV-MFRSR }\end{array}$ & $\begin{array}{l}\text { Greenbelt, } \\
\text { MD/summer } \\
2003\end{array}$ & $\begin{array}{l}325 \mathrm{~nm} \\
332 \mathrm{~nm} \\
368 \mathrm{~nm}\end{array}$ & 0.028 & Not specified ${ }^{k}$ & $\begin{array}{l}\text { Not } \\
\text { specified }^{\mathrm{k}}\end{array}$ & $\begin{array}{l}0.92^{\mathrm{p}} \\
0.92^{\mathrm{p}} \\
0.94^{\mathrm{p}}\end{array}$ \\
\hline Krotkov et al. (2005c) & $\begin{array}{l}\text { Modeling of DDR from } \\
\text { UV-MFRSR }\end{array}$ & $\begin{array}{l}\text { Greenbelt, MD/10 } \\
\text { Nov } 2003\end{array}$ & $325 \mathrm{~nm}$ & $0.02^{\mathrm{h}}$ & Not specified ${ }^{\mathrm{k}}$ & $\begin{array}{l}\text { Not } \\
\text { specified }^{n}\end{array}$ & $\begin{array}{l}0.83- \\
1.0\end{array}$ \\
\hline Bais et al. (2005) & $\begin{array}{l}\text { Modeling of DDR from } \\
\text { Brewer spectroradiometer } \\
\text { measurements }\end{array}$ & $\begin{array}{l}\text { Thessa-loniki, } \\
\text { Greece/Mar-Apr } \\
2001 \\
\text { ( } 2 \text { cases) }\end{array}$ & $368 \mathrm{~nm}$ & $0.03^{\mathrm{b}}$ & Not specified ${ }^{1}$ & $0.7^{\mathrm{b}}$ & $\begin{array}{l}0.8- \\
0.9 \\
0.65- \\
0.8\end{array}$ \\
\hline Barnard et al. (2008) & $\begin{array}{l}\text { Inversion of actinic flux } \\
\text { measurements from spec- } \\
\text { troradiometer }\end{array}$ & $\begin{array}{l}\text { Mexico City } \\
\text { (MCMA), April } \\
2003\end{array}$ & $300 \mathrm{~nm}$ & Not specified $^{\mathrm{i}}$ & Not specified ${ }^{\mathrm{m}}$ & $\begin{array}{l}\text { Not } \\
\text { specified }^{\mathrm{O}}\end{array}$ & $\begin{array}{l}0.67- \\
0.78\end{array}$ \\
\hline
\end{tabular}

a Deduced from fits.

b Assumed.

c Determined from satellite data.

${ }^{\mathrm{d}}$ Extrapolated from visible MFRSR-derived $\tau$ using a linear Angström exponent.

e Determined from double Brewer spectroradiometer and lidar.

${ }^{\mathrm{f}}$ Determined from UV-MFRSR irradiances.

$\mathrm{g}$ Determined from iterative Mie calculation, with DMPS-measured aerosol size distributions and assumed real refractive index of 1.5.

$\mathrm{h}$ Determined from TOMS climatology.

${ }^{\mathrm{i}}$ Measured from G-1 in MILAGRO in visible; extrapolated to UV.

j Determined from UV- MFRSR cosine corrected voltages and AERONET transferred calibration constant (see text).

${ }^{\mathrm{k}}$ Determined from UV- MFRSR, but with AERONET transferred calibration (see text).

${ }^{1}$ Determined from direct irradiance measurements.

$\mathrm{m}$ Determined from direct beam inversions of visible MFRSR data.

${ }^{\mathrm{n}}$ Determined from iterative Mie calculations using AERONET-retrieved size distribution and real part refractive index.

${ }^{o}$ Determined from iterative Mie calculations using retrieved size distribution and refractive index at $415 \mathrm{~nm}$.

$\mathrm{p}$ Average value.

the same methodology as in Wenny et al. (1998), except they added a recalibration of the $\tau$ and DDR measurements using separate, co-located AERONET Sun photometer measurements, as described below, and inputs of size distributions and real refractive indices retrieved from AERONET inversions of Sun-sky almucantar measurements at visible wavelengths. We note that more recently, Goering et al. (2005), Taylor et al. (2008) and Kudo et al. (2008) have proposed 
optimal estimation techniques for the simultaneous retrieval of spectral aerosol optical properties by combining measurements at several wavelengths; although a priori constraints are also needed in those schemes, they are applied differently than in the single wavelength methods focused on here.

In this work, we present estimates of aerosol singlescattering albedo $\omega$ at two independently retrieved UV wavelengths, 332 and $368 \mathrm{~nm}$, for a site just north of the Mexico City basin. Our estimates use measurements of DDR at UV wavelengths made at the T1 site as part of the Megacity Initiative: Local and Global Research Objectives (MILAGRO) field campaign conducted in and around Mexico City, Mexico in March 2006. The MILAGRO campaign included a suite of gas-phase and aerosol-phase measurements on a number of measurement platforms including groundbased and aircraft. Instruments were located at three main ground-based sites, with the T1 site chosen to be representative of regions influenced by a mixture of fresh and aged pollutants exiting the greater Mexico City metropolitan area (Fast et al., 2007). Although the selection of the month of March for the MILAGRO study was based in part on the expectation of relatively low fire activity, as compared with later in the spring, observations showed significant fire activity and analyses suggested that the MILAGRO sites were impacted by biomass burning emissions (e.g., Moffet et al., 2008; Yokelson et al., 2008; Stone et al., 2008), including local grass fires at the T1 site (Marley et al., 2009). A temporary United States Department of Agriculture (USDA) UV-B Monitoring and Research Program (UVMRP; http://uvb.nrel.colostate.edu/) research station located at the $\mathrm{T} 1$ site $\left(19.70^{\circ} \mathrm{N}, 98.99^{\circ} \mathrm{W}, 2270 \mathrm{~m}\right)$ yielded necessary $\tau$ and DDR data for nearly the entire field campaign. The data were measured every $20 \mathrm{~s}$ and are archived at http://uvb.nrel.colostate.edu/. A CIMEL Sun photometer also collected $\tau$ and aerosol inversion data at T1 as part of the AERONET network. Raw $\tau$ data are available at approximately $15 \mathrm{~min}$ resolution at http://aeronet.gsfc.nasa.gov.

\section{Retrieval techniques}

As done in the prior studies summarized in Table 1, the retrieval of aerosol optical properties is accomplished by fitting modeled DDR to the observations. The Tropospheric Ultraviolet model (TUV) version 4.4 was used for all radiative transfer calculations (Madronich and Flocke, 1999; http://cprm.acd.ucar.edu/Models/TUV/). As explained by Petters et al. (2003), the TUV4.4 output of direct horizontal irradiance normalized to extraterrestrial solar irradiance was divided by the cosine of SZA, to match the output of the UV-MFRSR, which archives the direct normal voltage. The DDR is then computed from the measurements as the ratio of the direct normal voltage to the diffuse horizontal voltage and compared to the ratio of the similar solar normalized irradiances from the model. Values of DDR were calculated using the 4-stream discrete ordinate solver, using over 80 equallyspaced vertical layers, for the two longest UV-MFRSR spectral channels centered at $368 \mathrm{~nm}$ and $332 \mathrm{~nm}$. The default vertical aerosol profile in TUV4.4 used to scale the input $\tau$ is the continental aerosol profile reported by Elterman et al. (1969) with a scale (e-folding) height of about $4 \mathrm{~km}$. TUV inputs of latitude and longitude, SZA, climatological column $\mathrm{NO}_{2}$, and surface pressure for the $\mathrm{T} 1$ site were obtained from the AERONET database (http://aeronet.gsfc.nasa.gov). Ozone column data were obtained from the Ozone Monitoring Instrument (OMI) on board the NASA Aura satellite.

The remaining required TUV inputs for each wavelength are $\tau, g, \omega$, and surface albedo. The measurements, used to determine both $\tau$ and DDR, were obtained using a UV Multifilter Shadowband Radiometer (UV-MFRSR; Bigelow et al., 1998), which measures voltages proportional to the total and diffuse horizontal irradiances at $300,305,311,317,325$, 332 , and $368 \mathrm{~nm}$ with nominal $2 \mathrm{~nm}$ resolution (full width at half maximum, FWHM). Total horizontal voltages are measured when the shadowband is at rest to the side of the diffuser and diffuse horizontal voltages are measured with the shadowband completely shadowing the diffuser. Diffuse horizontal voltages are corrected for excess sky blocking internally using additional blocking measurements at $9^{\circ}$ off to each side of the direct-sun shadowband position (Harrison et al., 1994). The subtraction of the corrected diffuse horizontal voltages from the total horizontal voltages yields direct horizontal voltages that are converted to direct normal voltages using laboratory measured angular response functions.

The raw voltage signals $(\mathrm{mV})$ measured by UV-MFRSR are first corrected for non-cosine angular response and dark current and then converted to dimensionless transmittance values using channel-specific calibration coefficients, $V_{0, \lambda}$ $(\mathrm{mV}) . V_{0, \lambda}$ values are determined using either an on-site Langley regression method (Harrison and Michalsky, 1994; Slusser et al., 2000) or using calibration transfer from a colocated AERONET Sun photometer (Krotkov et al., 2005a), and the equation:

$\ln V_{\lambda}=\ln V_{o, \lambda}-m \tau_{\mathrm{TOT}}$

where $V_{\lambda}$ is the measured direct normal voltage and $m$ is the air mass factor (secant of the solar zenith angle, SZA). The on-site Langley method assumes constant total optical depth $\tau_{\text {TOT }}$ and extrapolates via a linear regression between $m$ and $\ln V_{\lambda}$ to zero airmass $(m=0)$ to estimate $V_{0, \lambda}$ as the intercept value (Bigelow et al., 1998). The same calibration constant can be used for both the diffuse and direct measurements. The main difficulty of the local Langley calibration method is that at most sites, $\tau_{\text {TOT }}$ does not remain constant during the calibration period (typically a few morning hours), which results in significant errors in the estimated $V_{0, \lambda}$. To smooth out these errors, a statistical regression is fit to the daily $V_{0, \lambda}$ values to determine smoothed $\left\langle V_{0, \lambda}\right\rangle$ values, representative of degradation of the throughput of the instrument, that are 


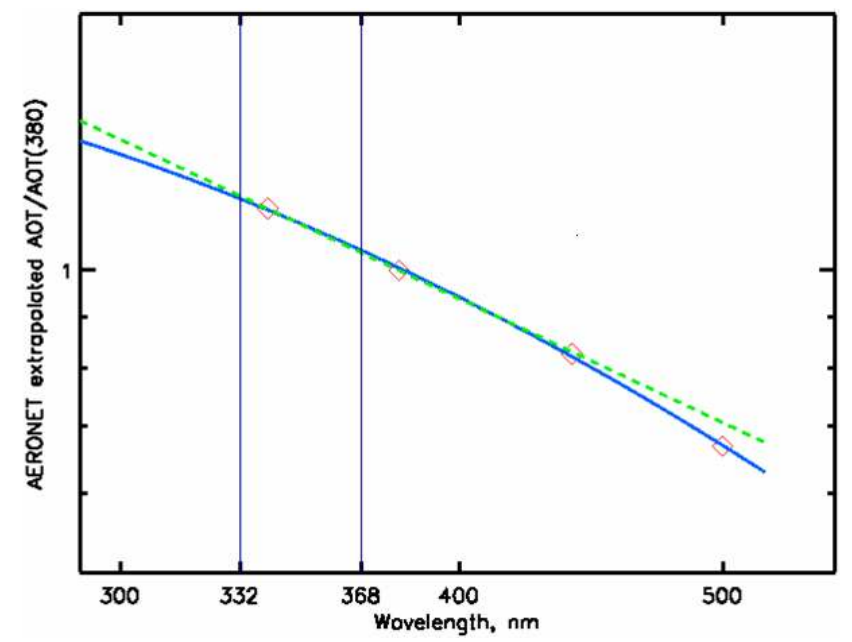

Fig. 1. Spectral interpolation/extrapolation of AERONET $\tau$ values $(340 \mathrm{~nm}, 380 \mathrm{~nm}, 440 \mathrm{~nm}, 500 \mathrm{~nm})$ to the UV-MFRSR spectral channels (shown in vertical blue lines). The green dashed line is the linear fit for the 340-380 nm Angström Exponent. The blue curve is a quadratic least-squares fit of the Angström Exponent to all four AERONET channels.

later used to solve Eq. (5) for $\tau_{\text {TOT }}$ for each individual UVMFRSR measurement:

$\tau_{\mathrm{TOT}}=\frac{1}{m}\left[\ln <V_{o, \lambda}>-\ln V_{\lambda}\right]$

Subtracting Rayleigh and gaseous optical thicknesses from $\tau_{\text {TOT }}$ yields aerosol optical depth, $\tau$.

The statistical method (Eq. 6) works best for relatively cloud free and pollution free locations, where atmospheric stability requirements are frequently met. However, in polluted locations, the data available to estimate $\left\langle V_{0, \lambda}\right\rangle$ may be sparse because of few clear-sky measurements. Further, it has been shown that the UV-MFRSR instrument can experience rapid and non-monotonic throughput changes due to diffuser soiling and self-cleaning (after rain events) (Krotkov et al., 2005a), so that the accuracy of the on-site statistical Langley technique is not always sufficient for aerosol retrieval applications (Michalsky et al., 2001). An independent check on the validity of the derived $V_{0, \lambda}$ can be made using co-located, well-calibrated AERONET data, as explained in detail below. AERONET sites are equipped with the CIMEL Electronique 318A, an automatic sun-tracking and sky scanning filter radiometer, and undergo standardized calibration procedures (Holben et al., 1998). The instrument has two detectors for the measurement of Sun/aureole and sky radiances. Eight ion-assisted deposition interference filters yield direct-Sun radiance measurements at $340 \mathrm{~nm}, 380 \mathrm{~nm}$, $440 \mathrm{~nm}, 500 \mathrm{~nm}, 670 \mathrm{~nm}, 870 \mathrm{~nm}, 940 \mathrm{~nm}$, and $1020 \mathrm{~nm}$ with band passes (FWHM) of $2 \mathrm{~nm}$ for the $340 \mathrm{~nm}$ channel, $4 \mathrm{~nm}$ for the $380 \mathrm{~nm}$ channel, and $10 \mathrm{~nm}$ for all visible wavelength channels (Holben et al., 2001). The CIMEL makes additional almucantar sky radiance measurements at $440 \mathrm{~nm}, 670 \mathrm{~nm}$,

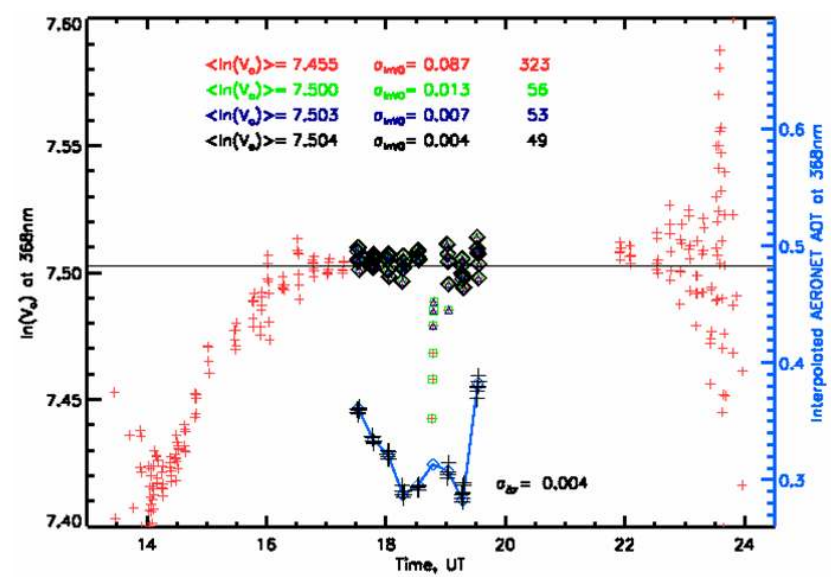

Fig. 2. Iterative screening process as applied to the determination of $\ln \left(V_{0}\right)$ at $368 \mathrm{~nm}$ for the UV-MFRSR instrument (left axis), using AERONET direct-Sun $\tau$ data at the T1 site on 12 March 2006 (DOY 71). The inset lists sample average value for $\ln \left(V_{0}\right)\left(<\ln \left(V_{0}\right)>\right)$, sample standard deviation of $\ln \left(V_{0}\right)\left(\sigma_{\ln V 0}\right)$, and number of measurements in the sample for each iteration. Red crosses: UV-MFRSR raw $V_{0}$ data. Black diamonds: estimated $V_{0}$ after filtering to 49 points (see text). Black horizontal line: final daily average $V_{0},\left\langle V_{0}\right\rangle$, applied to UV-MFRSR data. Black crosses (right axis): derived UV-MFRSR $\tau_{368}$ using $\left\langle V_{0}\right\rangle$. Blue diamonds (right axis): Interpolated AERONET $\tau_{368}$. The RMS difference between AERONET and UV-MFRSR AOT in the final daily sample is within stated uncertainty of AERONET measurements $(\sim 0.004)$.

$870 \mathrm{~nm}$, and $1020 \mathrm{~nm}$ during each measurement sequence that are inverted together with direct sun data to estimate particle size distributions and refractive indices (real and imaginary parts) in the visible wavelengths (Dubovik and King, 2000; Dubovik et al., 2000).

In our study values of $V_{0 \lambda}$ at 332 and $368 \mathrm{~nm}$ were obtained by combining UV-MFRSR direct voltages with AERONET $\tau$ values, satellite ozone values and climatological $\mathrm{NO}_{2}$ values, using the methodology described by Krotkov et al. (2005a, b). First, $\tau$ values at UV-MFRSR wavelengths 332 and $368 \mathrm{~nm}$ were interpolated/extrapolated spectrally using a quadratic least squares fit of $\ln (\lambda)$ versus $\ln (\tau$ for standard AERONET $\tau$ data at 340, 380, 440 and $500 \mathrm{~nm}$ (Fig. 1). These values of $\tau_{368}$ and $\tau_{332}$, along with appropriate values of Rayleigh, $\mathrm{NO}_{2}$ and $\mathrm{O}_{3}$ optical thicknesses calculated from the AERONET surface pressure and gaseous column concentration data, were used in Eq. (5) to determine $V_{0, \lambda}$ for each individual ( $20 \mathrm{~s})$ UV-MFRSR measurement. If all measurements are consistent, $V_{0, \lambda}$ should remain constant during the day regardless of any changes in atmospheric transmittance and/or solar elevation and azimuth. Therefore, examining diurnal trends in raw UVMRP $V_{0, \lambda}$ data provides insight into possible systematic calibration errors and yields a tool for screening non-consistent and/or outlier measurements in an iterative procedure. 
Figure 2 demonstrates the iterative screening process used to find suitable time periods and corresponding mean daily $\left\langle V_{0, \lambda}\right\rangle$, as applied to the determination of $V_{0,368}$ on 12 March. We initially screened the UV-MFRSR data to select only points within $1 \mathrm{~min}$ of AERONET $\tau$ retrievals, resulting in an initial set of 323 UV-MFRSR measurements for this day. Measurements in early morning (before 14:00 UT, where local time $=\mathrm{UT}-6)$ and evening (after 22:00 UT) were rejected because of increased noise due to low signal level. Late morning $V_{0,368}$ data (14:00 UT-16:00 UT), although less noisy, exhibited a systematic increase with SZA and were rejected for that reason. During the noon period (17:00 UT-20:00 UT), $V_{0,368}$ remained reasonably constant (standard deviation $\sim 1 \%$ ) and these data were used for calculating mean daily $\left\langle V_{0,368}\right\rangle$ to reduce random noise in individual measurements. The noise was further reduced (by a factor of 3) by removing outlier measurements (those with $\ln \left(V_{0,368}\right)$ outside of $\pm 2 \sigma$ of the $\ln <V_{0,368}>$ ) and iteratively re-calculating $\left\langle V_{0,368}\right\rangle$. The final $\left.\ln <V_{0,368}\right\rangle$ was used in Eq. (6) to calculate UV-MFRSR $\tau_{368}$ that agree with AERONET-interpolated $\tau_{368}$ within an rms difference of $\sim 0.004$ for the selected time interval (i.e., between 17:00 and 20:00 UT). The $<V_{0,368}>$ was also used to normalize diffuse and total UV-MFRSR cosine corrected voltages to obtain corresponding dimensionless transmittances. The screening procedure reduced the 323 raw UV-MFRSR measurements to a final filtered data set of 49 points retained for $\omega$ retrievals on this day. Similar calibration results were obtained on other days selected for single scattering albedo retrievals, except on 19 March, affected by dust as explained later.

We obtained estimates of $\omega_{368}$ and $\omega_{332}$ using two approaches: the Krotkov et al. (2005a, b) methodology (hereafter called the "Krotkov method"), and a modified version of the Petters et al. (2003) technique (hereafter referred to as "this work"). The two approaches differ in the assumptions used to determine a key input for TUV4.4, the asymmetry parameter, $g$. In this work, rather than assuming a fixed climatological or measured value for $g$, we ran multiple simulations for a range of $g$ values applicable to the expected aerosol types. To determine an appropriate range in $g$, we used data from an AERONET site that has been located in Mexico City $\left(19.33^{\circ} \mathrm{N}, 99.18^{\circ} \mathrm{W}, 2268 \mathrm{~m}\right)$ since March 1999. We downloaded all valid Version 2 retrievals for March dates in all available years (1999-2008) and computed a median $g_{440}$ of $0.68 ; 96 \%$ of the values were between 0.6 and 0.75 . These historical data agreed well with the Level 1.5, Version 2 AERONET almucantar retrievals reported for the T1 site for March 2006: median $g_{440}, 0.68$; min, 0.63; max, 0.74. We note that for small particles, $g$ is expected to increase at UV wavelengths. Accordingly, Barnard et al. (2008) estimated $g_{300}=0.76-0.77$ and $g_{500}=0.70-0.72$ for Mexico City aerosol for five days in the MCMA-2003 field campaign. We thus chose $0.6 \leq g \leq 0.75$ as the input range of $g_{332}$ and $g_{368}$, and computed all pairs of $g$ and $\omega$ that yielded modeled DDR in agreement with (within
$1 \%$ relative error) the measurements. In the Krotkov method, the values of $g$ and $\omega$ are determined from a separate Mie calculation. The method requires successful AERONET almucantar retrievals near the time periods of interest in order to initialize the size distribution and real refractive index, $n$, in the Mie code. The shortest wavelength at which $n$ is retrieved is $440 \mathrm{~nm}$, and this value was assumed to apply also at 368 and $332 \mathrm{~nm}$. The imaginary part of the refractive index at each wavelength was then varied iteratively, until the $g$ and $\omega$ computed from the Mie code yielded a modeled DDR in agreement with the UV-MFRSR observations.

Retrievals of $\omega$ from observed DDR are sensitive to the choice of surface albedo, assumed in our modeling to be Lambertian. A higher surface albedo will increase the diffuse component of the radiation field and therefore decrease the DDR. Retrievals that underestimate the surface albedo therefore incorrectly attribute some of the diffuse radiation to aerosols, leading to an overestimation of $\omega$ if the aerosol optical depth is specified independently (e.g., from direct sun AERONET data, as done here). We show retrievals for two assumptions: a spectrally flat surface albedo of 0.06 consistent with the surface albedo of urban surfaces (Castro et al., 2000), and a spectrally-varying surface albedo, estimated from measurements during MILAGRO from aircraftbased radiometers. Surface albedo measurements by Coddington et al. (2008) from the J-31 aircraft spanned the wavelength range $350-2000 \mathrm{~nm}$; although reported measurements in the UV range are sparse, they show values of $0.07-0.08$ at $385 \mathrm{~nm}$ with a systematic decrease towards lower wavelengths. Madronich et al. (2007) compared spectral actinic fluxes measured at the T1 surface site with upwelling spectral actinic fluxes measured from $\mathrm{T} 1$ overpasses by the C-130 aircraft, and found that a spectrally dependent surface albedo was required over the wavelength range $300-420 \mathrm{~nm}$, to explain the wavelength variation of the actinic flux under both clean and polluted conditions. This wavelength-dependent surface albedo was approximated by Madronich et al. (2007) with a linear interpolation between a value of 0.02 at $320 \mathrm{~nm}$ and 0.10 at $400 \mathrm{~nm}$. We slightly revised this estimate here to a linear variation between 0.015 at $320 \mathrm{~nm}$ and 0.085 at $400 \mathrm{~nm}$, based on the lower values for $385 \mathrm{~nm}$ reported by Coddington et al. (2008). Interpolation then yields surface albedos of 0.025 at $332 \mathrm{~nm}$ and 0.057 at $368 \mathrm{~nm}$. While this difference of 0.032 albedo units may seem small, it will be shown below that it has a significant influence on the spectral dependence of retrieved $\omega$.

It should be noted that error may also be introduced in the retrieval of $\omega$ with the assumption of a fixed $\mathrm{NO}_{2}$ column concentration such as that used in this work's retrievals. Studies have shown that the use of the climatological $\mathrm{NO}_{2}$ value will result in an underestimation of $\omega$ during high pollution episodes (Krotkov et al., 2005c). While the fixed $\mathrm{NO}_{2}$ value of $\sim 0.4 \mathrm{DU}\left(1.1 \times 10^{16}\right.$ molecules $\left./ \mathrm{cm}^{2}\right)$ used in all $\omega$ retrievals is consistent with that used in the AERONET inversions as well as with the background $\mathrm{NO}_{2}$ value observed 
at the T1 site during MILAGRO (Johansson et al., 2009), such a value may not be representative of short-lived pollution plumes that passed over the T1 site during MILAGRO. It can be shown that the error in retrieved $\Delta \omega$ is determined by the ratio of $\mathrm{NO}_{2}$ and aerosol extinction optical thickness at particular wavelength:

$$
\frac{\Delta \omega}{\omega} \sim \frac{\Delta \tau_{\mathrm{NO} 2}}{\tau}
$$

Use of background $\mathrm{NO}_{2}$ concentration when actual $\mathrm{NO}_{2} \sim 2 \mathrm{DU}\left(5 \times 10^{16}\right.$ molecule $\left./ \mathrm{cm}^{2}\right)$ under conditions with low aerosol loading $\left(\frac{\tau_{\mathrm{NO} 2}}{\tau} \sim 0.2, \tau_{\mathrm{NO} 2} \sim 0.03\right.$ and $\tau \sim 0.15$ at $368 \mathrm{~nm})$ results in significant underestimation of the retrieved $\omega$ at least $12 \%$ and $7 \%$ at $368 \mathrm{~nm}$ and $332 \mathrm{~nm}$, respectively (Krotkov et al., 2005c). Accounting for $\tau$ spectral dependence in Eq. (7) the $\mathrm{NO}_{2}$ error is even larger at $440 \mathrm{~nm}\left(\Delta \tau_{\mathrm{NO} 2}\right.$ being approximately the same at $368 \mathrm{~nm}$ and $440 \mathrm{~nm}$, but $\tau(368)>\tau(440)$ ). Therefore, under low aerosol loading conditions the $\mathrm{NO}_{2}$ error can change significantly not only the absolute value of $\omega$, but also $\omega$ spectral dependence. However, the error becomes practically negligible for aerosol laden pollution plumes when the ratio $\frac{\tau_{\mathrm{NO} 2}}{\tau}$ is small.

\section{Results and discussion}

Although AERONET and UVMRP data are available for most of the days in March 2006, our screening procedures have limited retrievals to days with valid cloud-screened AERONET almucantar (Version 2) retrievals, needed to initialize the size distributions in the Krotkov method. AERONET almucantar inversions require SZA $>45^{\circ}$ (Dubovik and King, 2000; Dubovik et al., 2000), while UV-MFRSR voltage corrections and derived aerosol optical depths are most accurate at SZA smaller than $70^{\circ}$, due to increases in angular response errors at larger SZA (Krotkov et al., 2005a). This limitation is more severe at the surface elevation of Mexico City than at sea level, because of the relatively larger importance of the direct solar beam.

The cloud-free periods that we chose corresponded to $19^{\circ}<\mathrm{SZA}<53^{\circ}$, and thus the retrieved size distributions and real refractive indices used to initialize the Krotkov method were mostly determined for times before or after our $\omega$ retrieval periods. The relationship between $\tau, \omega$, and DDR is shown in Fig. 3. As $\tau$ decreases, particularly for $\tau<0.2$, DDR becomes increasingly less sensitive to values of $\omega$ and the best-fit $\omega$ is not sufficiently constrained. Thus, we limited retrievals to periods with $\tau_{368}>0.1$, recognizing that large uncertainties may be associated for cases when $\tau_{368}<0.2$. Applying all of these screening criteria, the final dataset for which we will report $\omega$ retrievals was limited to relatively short near-noon periods on 12, 13, and 21 March 2006, as summarized in Table 2. An additional retrieval was performed for 19 March 2006 using $\tau_{368}$ and $\tau_{332}$ determined using AERONET non-cloud screened Level 1.0

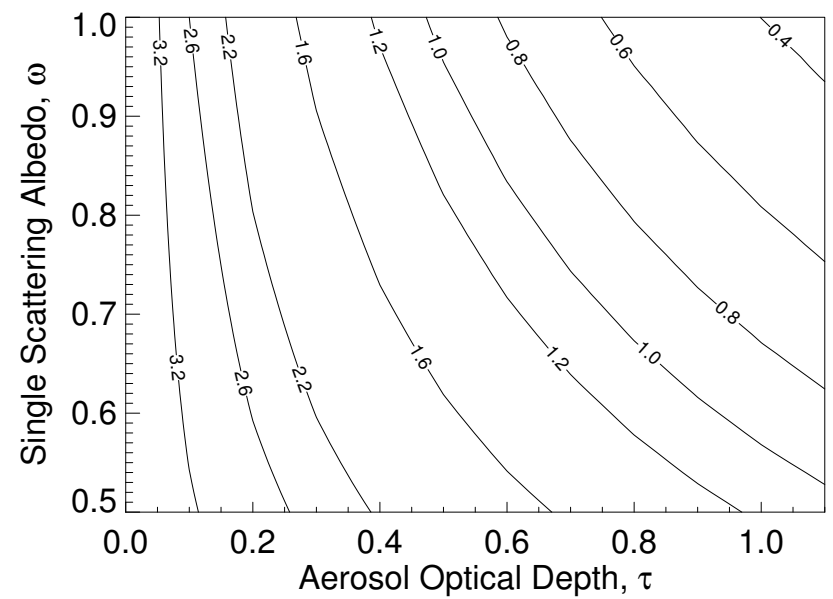

Fig. 3. Contours of DDR (direct-to-diffuse irradiance) computed at $368 \mathrm{~nm}$, as a function of $\tau_{368}$ and $\omega_{368}$ for fixed value of $g_{368}$ (0.70), SZA $\left(40^{\circ}\right)$, and surface albedo (0.06).

$\tau$ data. As discussed further below, we determined that the AERONET cloud-screening algorithm used to create Level 1.5 and Level 2.0 datasets also removed cloud-free periods heavily influenced by dust.

Timelines for 10 March (DOY 69) through 31 March (DOY 90) of $\tau_{380}$ obtained at T1 from AERONET Version 2 direct Sun inversions, Levels 1.0 and 2.0 quality screened, are shown in Fig. 4, with the periods for which $\omega$ retrievals were conducted highlighted. The time periods of the three meteorological regimes defined for the MILAGRO study by Fast et al. (2007) are also indicated. During regime 1, early in the month, mostly sunny and dry conditions prevailed, leading to elevated dust concentrations in addition to smoke aerosols from numerous fires. The passage of a cold surge on 14 March marked a transition to a period with more frequent afternoon partial cloudiness. Another cold surge late in the day on 21 March marked the transition to regime 3, a period of increased convection and cloudiness and reduced number and intensity of fires in the region. Figure 10 in Fast et al. (2007) shows the timeline of shortwave radiation measured at $\mathrm{T} 1$ and confirms that our four selected days had low overall fractional cloudiness and extended periods of cloudfree conditions, as required for our retrieval methods. Fast et al. (2007) estimate that transport from Mexico City to the T1 site was likely on three of the days we selected for analysis, 12, 19 and 21 March. The relatively low optical depths in the morning on 19 March (Fig. 7 in Fast et al., 2007) are consistent with the detailed meteorological analyses of deFoy et al. (2008), who noted that persistent southerly winds aloft contributed to very clean air on this day. The timeline of daily afternoon $\mathrm{CO}$ concentrations simulated for the $\mathrm{T} 1$ site that is presented in Fig. 19 of Fast et al. (2007), when compared with Fig. 4, demonstrates a general correspondence between elevated (CO) and elevated $\tau_{368}$. 


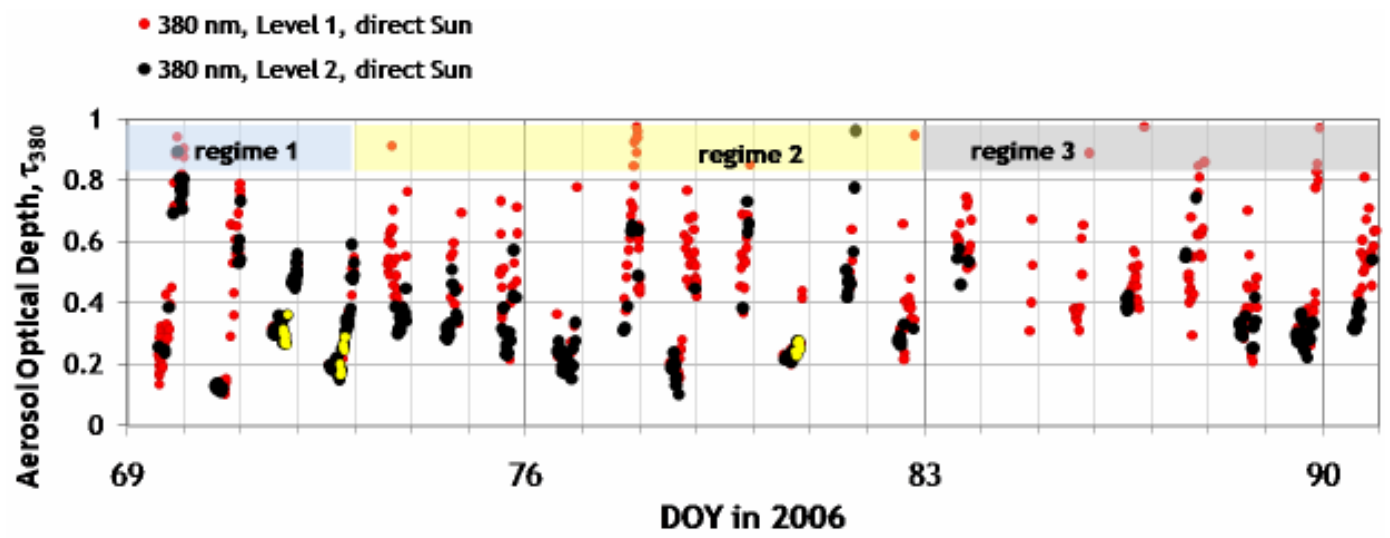

Fig. 4. Timeline of $\tau_{380}$ determined from AERONET direct-Sun inversions at the T1 site, for 10 March (DOY 69) through 31 March (DOY 90). Data are Level 2 (black) cloud-screened and Level 1 unprocessed (red). The yellow-highlighted points show the periods for which $\omega$ retrievals were conducted. The labels at the top indicate the days corresponding to the meteorological regimes identified by Fast et al. (2007).

Table 2. Days during March 2006 for which retrievals were conducted for data from the T1 site, together with values for some of the required TUV4.4 input parameters. The final four columns show the retrieved ranges of $\omega_{368}$ and $\omega_{332}$ for the indicated assumed values of surface albedos, using the aerosol optical depths obtained from the adjusted $V_{0, \lambda}$ (columns 7 and 8).

\begin{tabular}{cccccccccccc}
\hline & & & \multicolumn{2}{c}{ adjusted $V_{0, \lambda}$} & \multicolumn{2}{c}{ unadjusted $V_{0, \lambda}$} & \multicolumn{2}{c}{ surface albedo=0.06 } & \multicolumn{2}{c}{$\begin{array}{c}\text { spectrally-varying } \\
\text { surface albedo }\end{array}$} \\
DOY & day & time (UT) & $\tau_{368}$ & $\tau_{332}$ & $\tau_{368}$ & $\tau_{332}$ & $\omega_{368}$ & $\omega_{332}$ & $\omega_{368}$ & $\omega_{332}$ \\
\hline 71 & 12 & $1730-2000$ & $0.28-0.38$ & $0.31-0.43$ & $0.33-0.43$ & $0.39-0.50$ & $0.75-0.82$ & $0.76-0.80$ & $0.75-0.83$ & $0.78-0.82$ \\
72 & 13 & $1730-2000$ & $0.16-0.30$ & $0.19-0.34$ & $0.21-0.36$ & $0.27-0.42$ & $0.73-0.79$ & $0.70-0.76$ & $0.73-0.79$ & $0.74-0.78$ \\
80 & 21 & $1730-2000$ & $0.23-0.29$ & $0.26-0.33$ & $0.27-0.34$ & $0.38-0.44$ & $0.79-0.85$ & $0.78-0.83$ & $0.79-0.85$ & $0.81-0.86$ \\
\hline
\end{tabular}

Figure 5 presents the retrieved ranges of $\omega_{368}$ and $\omega_{332}$ obtained in this work for 12, 13, and 21 March, assuming a spectrally flat surface albedo of 0.06 . The points represent the average of all possible $\omega_{368}$ and $\omega_{332}$ values for $g$ ranging from 0.6 to 0.75 , which we refer to as the range-averaged $\omega$ values. Estimated range-averaged $\omega_{368}$ and $\omega_{332}$ were lowest on 13 March, a day that was estimated to be least directly influenced by transport from Mexico City, with values remaining below 0.80 for the retrieval period. Range-averaged $\omega_{368}$ and $\omega_{332}$ were highest on 21 March, with values ranging from 0.79 to 0.85 for $\omega_{368}$ and from 0.78 to 0.83 for $\omega_{332}$.

Retrieval results for 19 March for this work are shown in Fig. 6, with retrievals using the Krotkov method overplotted. The latter method has fewer valid points because a stable $\left\langle V_{0}>\right.$ could be obtained for only a short morning time period. Most striking is the substantial decreases in both $\omega_{368}$ and $\omega_{332}$ between approximately 15.5 and 21 UT, corresponding to increases in $\tau$ (Fig. 6). Examination of ancillary data, including images from the Aqua and Terra satellite ( $250 \mathrm{~m}$ resolution) and images from an upward-pointing all-sky camera, showed cloud-free skies. However, airborne dust was clearly visible in the all-sky images and in pho- tographs of the surrounding area. Higher wind speeds were observed (5-10 $\mathrm{m} \mathrm{s}^{-1}$, compared to $1-5 \mathrm{~m} \mathrm{~s}^{-1}$ on 12,13 , and 21 March), and filter samples from T1 had elevated concentrations of $\mathrm{PM}_{2.5} \mathrm{Ca}^{2+}$ (A. Sullivan, personal communication), suggestive of crustal material. These findings are consistent with those of Querol et al. (2008) who reported large campaign mean concentrations of coarse mode material $\left(\mathrm{PM}_{10}\right)$ at the $\mathrm{T} 1$ suggesting elevated concentrations of dust at the measurement site compared to surrounding areas. Increases in dust concentrations were attributed to dust resuspension events during times of moderate to high wind speeds at the measurement site due to the $\mathrm{T} 1$ site's proximity to a cement plant and limestone quarry (Querol et al., 2008).

Several studies have observed stronger absorption of UV radiation than visible radiation by mineral dust (Bergstrom et al., 2004; Sokolik and Toon, 1999; Weaver et al., 2002; Wetzel et al., 2003). Thus, the decreases in $\omega_{368}$ and $\omega_{332}$ over this 7-h period on 19 March may be representative of enhanced UV absorption by dust particles passing over the site. However, errors in UV-MFRSR measurements are enhanced under high optical depth, dusty conditions. The empirical diffuse aureole correction uses sky brightness at $9^{\circ}$ from the 
Sun as a proxy for the aureole (Harrison at al., 1994). This proxy is an underestimation in general, but more so for dusty conditions, because larger particles, such as dust, preferentially forward scatter (larger $g$ ). The MFRSR diffuse voltage underestimation results in an overestimation of the MFRSR direct voltage, and thus an overestimation of the DDR. In our retrieval method, the overestimated DDR leads directly to underestimated $\omega$. Further, the values of $g$ assumed for our retrievals may be too low for the dusty conditions. Finally, we had difficulty obtaining stable $V_{0, \lambda}$ during most of this day, another indication that the standard MFRSR voltage corrections are not adequate. We conclude that evidence points to a change to a dust-dominated aerosol type during 19 March, with the late morning and afternoon aerosol having a lower $\omega$ than the aerosol observed on the other days, but the appropriate values of $\omega_{368}$ and $\omega_{332}$ cannot be established with confidence.

A few estimates of $\omega$ for Mexico City aerosols have been published to which our results for 12,13 and 21 March can be compared. Marley et al. (2009) computed $\omega$ at the T1 site in 2006 for visible wavelengths using ground-based aerosol absorbance and scattering measurements, and obtained an average value of 0.75 and a range $0.44-0.90$. Doran et al. (2007) used MFRSR data and the approach of Kassianov et al. (2005) to estimate $\omega_{500}$ at the T1 site during morning hours on DOY 71, 78 and 86, as $0.84,0.85$, and 0.89 . AERONET retrievals of $\omega_{441}$ at similar times on the respective days averaged $0.89,0.90$, and 0.92 , with $\omega_{674}$ averaging $0.88,0.89$, and 0.90. Marley et al.'s (2009) averages on these days were $0.76,0.79$, and 0.75 ; they attributed the discrepancies to the difference between their surface measurements that included fine particles only, and the column measurements that included all particles, as well as differences in the measurement wavelengths. The values obtained in this work for $\omega_{368}$ and $\omega_{332}$ on DOY 71 and 78 are in line with these other estimates, and indicate a generally decreasing $\omega$ with wavelengths shorter than $500 \mathrm{~nm}$, as also suggested by Barnard et al. (2008), who attributed the enhanced absorption in the near-UV to aerosol organic carbon. Figure 7 shows that the average $\omega_{368}$ and $\omega_{332}$ values retrieved for 12,13 and 21 March using the Krotkov method are substantially lower than AERONET $\omega_{441}$ and $\omega_{670}$ averaged over those same days. These findings are consistent with those reported by Barnard et al. (2008), who obtained $\omega_{500}=0.88-0.95$ (average of 0.92) and $\omega_{300}=0.67-0.78$ (average of 0.72) using MFRSR and actinic flux spectroradiometer data from the MCMA2003 field campaign in Mexico City (Fig. 7). As summarized in Table 2, our MILAGRO estimates of $\omega_{368}=0.73-$ 0.85 and $\omega_{332}=0.70-0.83$ are well aligned with their estimates at longer and shorter wavelengths, as is the AERONET $\omega_{441}=0.83-0.92$ at $\mathrm{T} 1$ for the same three days in 2006.

The spectroradiometer-derived $\omega_{\lambda}$ shown in Fig. 1 of Barnard et al. (2008) suggest no significant spectral dependence for $300 \mathrm{~nm}<\lambda<400 \mathrm{~nm}$. Our retrievals in Fig. 5 suggest only a small difference between $\omega_{368}$ and $\omega_{332}$, although
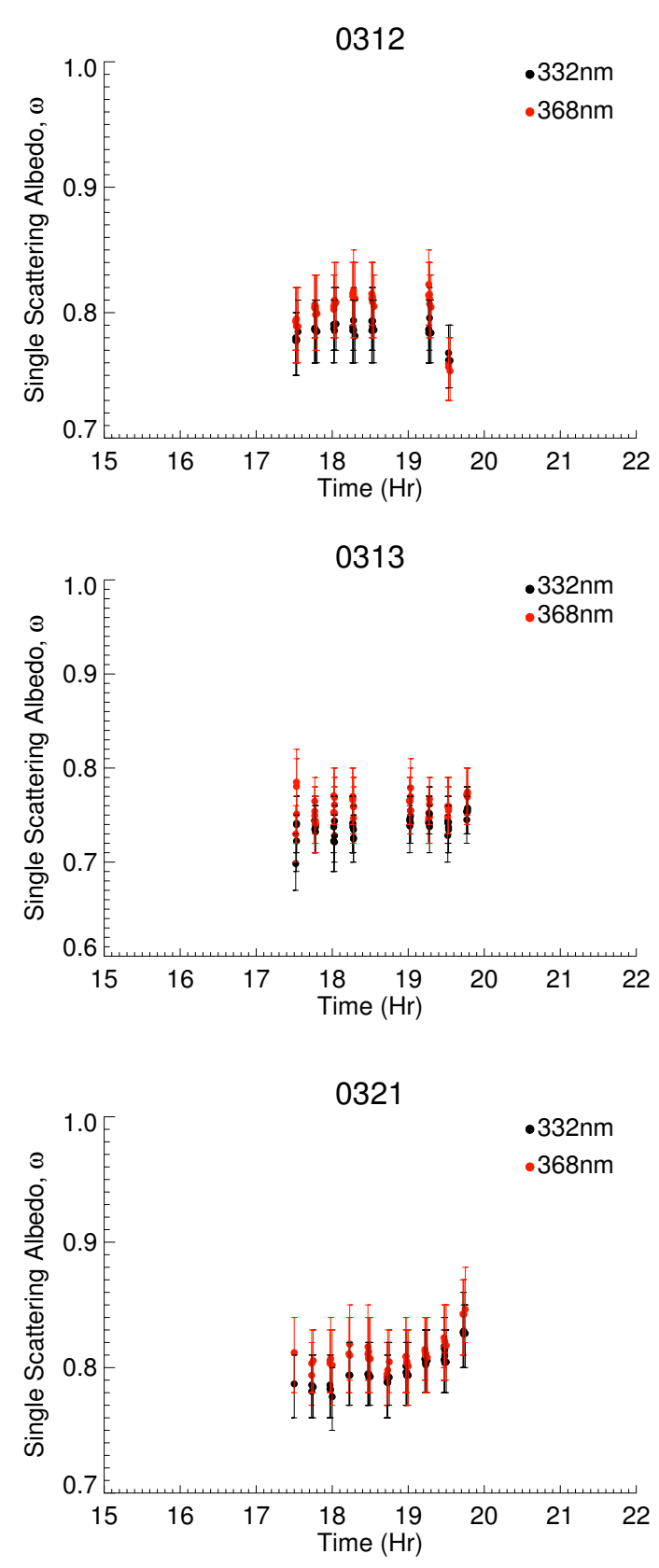

Fig. 5. Retrieved ranges of $\omega$ (bars) and range-averaged $\omega$ values (points) for $368 \mathrm{~nm}$ (red) and $332 \mathrm{~nm}$ (black), for 12, 13, and 21 March 2006 (DOY 71, 72, and 80). Surface albedo was fixed at 0.06 for both wavelengths.

a Student's t-test found that $\omega_{368}>\omega_{332}$ at the $95 \%$ confidence level for most of the retrievals on all retrieval days. In Fig. 8, we show retrieved $\omega$ assuming a spectrally-varying surface albedo, which resulted in higher range-averaged $\omega_{332}$ values. The revised retrievals for DOY 71 and 72 show almost no spectral dependence, and for DOY 80, the slight spectral variation has changed sign. 

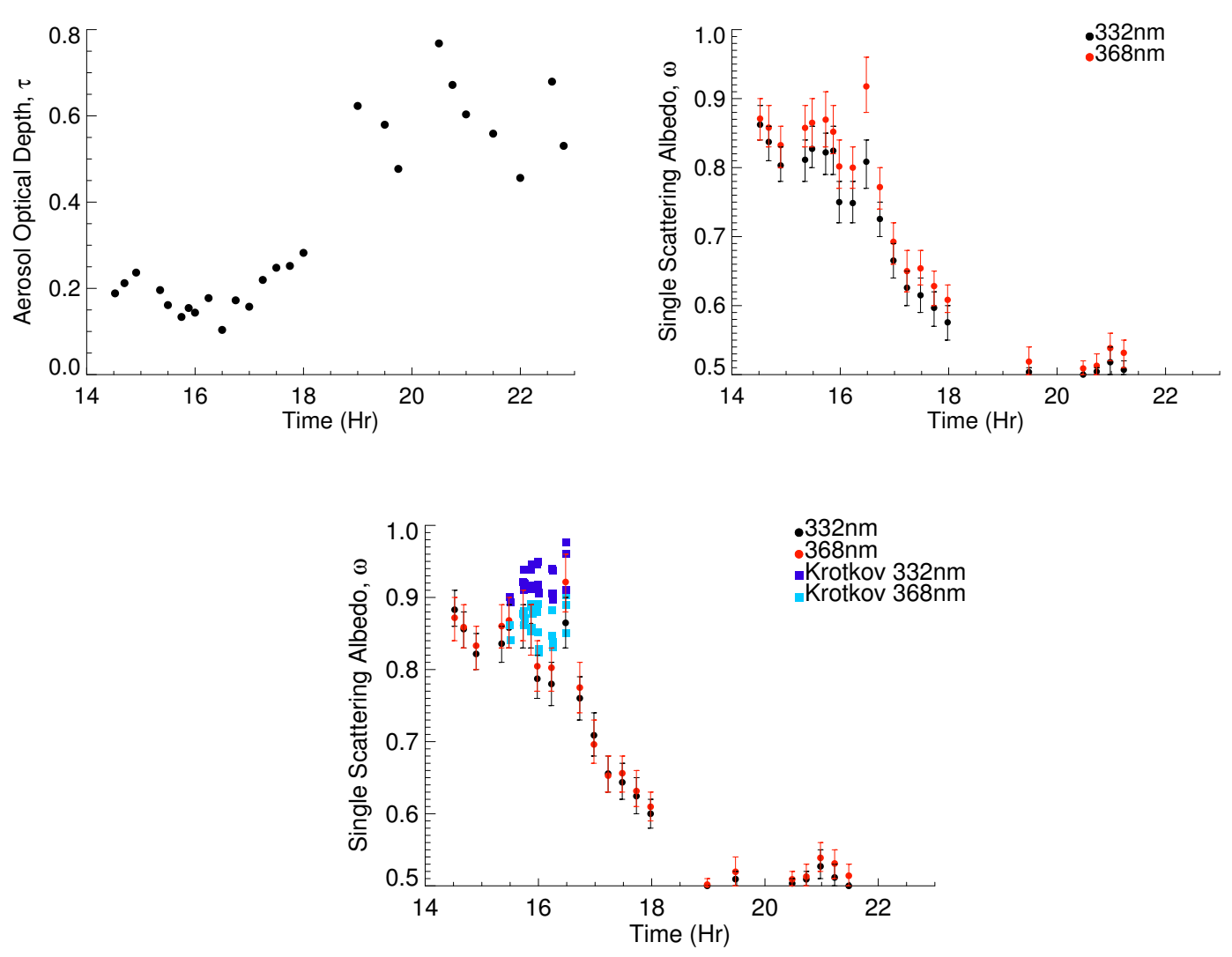

Fig. 6. Plots for 19 March showing AERONET Level $1.0 \tau_{380}$ (top, left), retrieved ranges of $\omega$ (bars) and range-averaged $\omega$ values (points) for $368 \mathrm{~nm}$ (red) and $332 \mathrm{~nm}$ (black) with surface albedo fixed at 0.06 for both wavelengths (top, right), and retrieved ranges of $\omega$ (bars) and range-averaged $\omega$ values (points) for $368 \mathrm{~nm}$ (red) and $332 \mathrm{~nm}$ (black), and $\omega$ values derived using the Krotkov method at $368 \mathrm{~nm}$ (dark blue) and 332 (light blue) with surface albedo assumed to have a wavelength dependence, with values set at 0.025 and 0.057 at $332 \mathrm{~nm}$ and $368 \mathrm{~nm}$ (bottom).

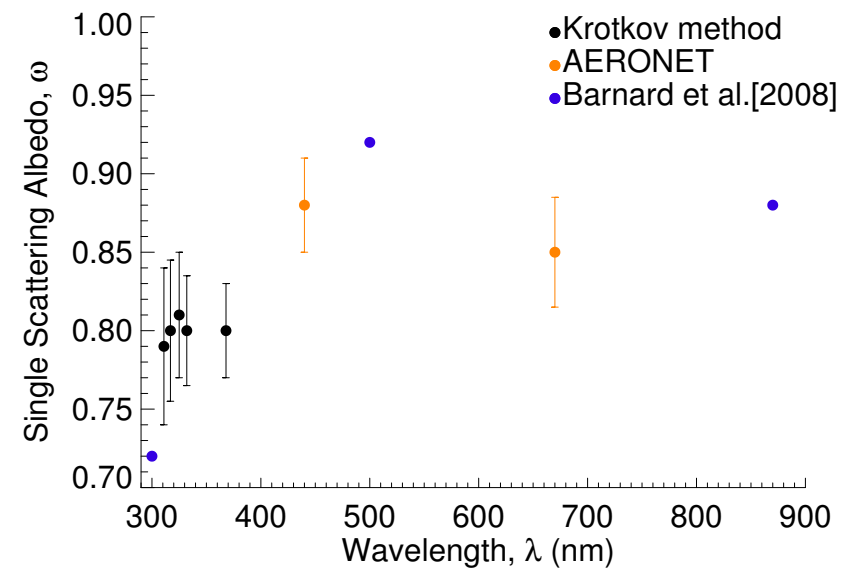

Fig. 7. $\omega$ values determined using the Krotkov method (black) and as reported by AERONET (orange) averaged over 12, 13, 21 March. Error bars represent the error in retrieved $\omega$ which is inversely proportional to $\tau$. Also shown are $\omega$ values averaged for five days in April 2003 determined by Barnard et al. (2008) using MFRSR and actinic flux spectroradiometer data from the MCMA-2003 field campaign in Mexico City.
Figure 9 compares the range-averaged $\omega_{368}$ and $\omega_{332}$ obtained in this work for the constant surface albedo case with the results obtained using the Krotkov method for the same time periods. The excellent agreement suggests that our choice of range for $g$ was appropriate for this application, and that using the uncorrected DDR (i.e., the $V_{0, \lambda}$ error cancellation for both diffuse and direct components) is adequate, as long as a corrected $\tau$ is input to the retrieval. Based on our calculations, the assumed range in $g$ leads to a range in $\omega$ of approximately 0.05 , within the \pm 0.025 cited by Barnard et al. (2008) although additional uncertainties must be added to our reported ranges.

One advantage of the method proposed in this work is that it does not require ancillary measurements of the aerosol size distribution, as do the Krotkov method and other approaches listed in Table 1. However, our results do demonstrate that accurate measurements of $\tau$ are the most critical for $\omega$ retrievals. In Fig. 9, the open symbols show the rangeaveraged $\omega_{368}$ and $\omega_{332}$ obtained using the uncorrected, onsite Langley-calibrated $\tau$ from the UVMRP website. As shown in Table 2, these uncorrected optical depths are significantly larger than those used in this work, by at least 0.04 

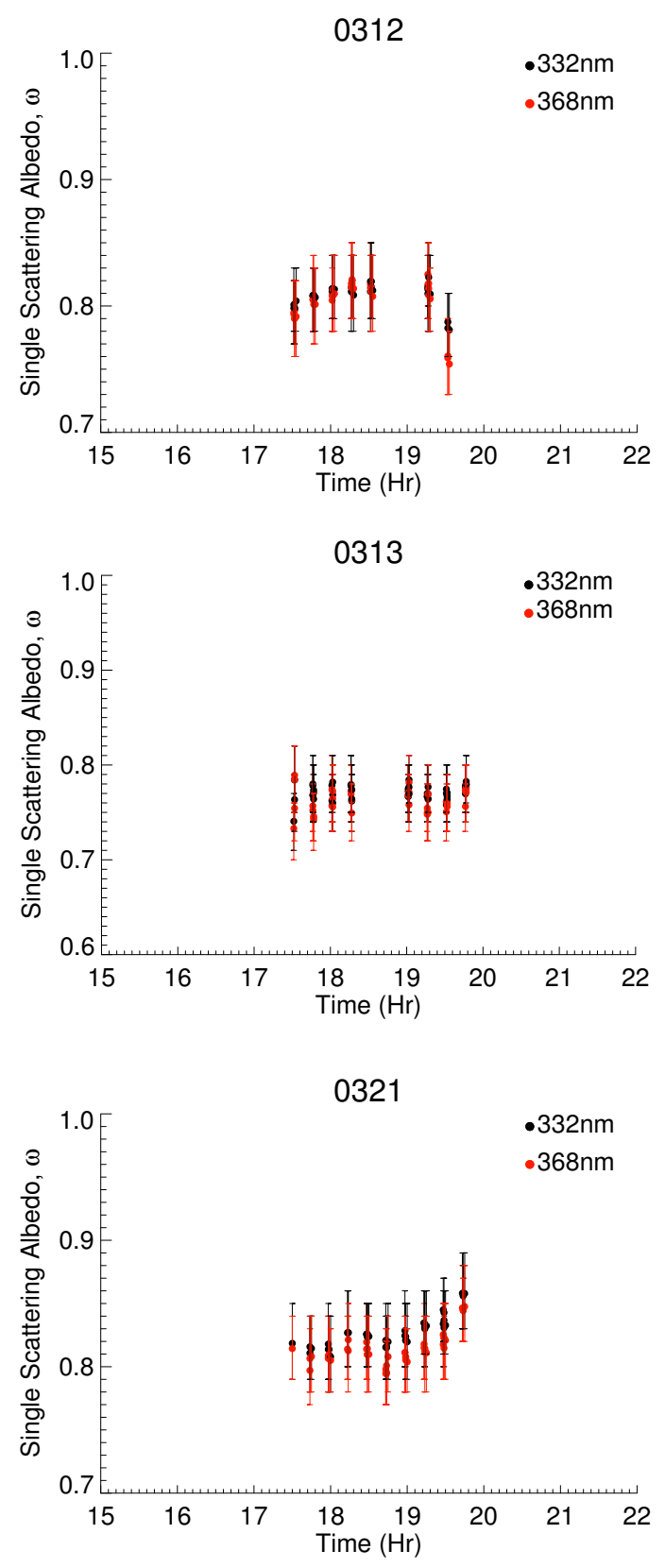

Fig. 8. As in Fig. 5, except that surface albedo was assumed to have a wavelength dependence, with values set at 0.025 and 0.057 at $332 \mathrm{~nm}$ and $368 \mathrm{~nm}$, respectively.

and by as much as 0.1. As can be seen from Fig. 3, an increase in $\tau$ at constant DDR implies a decrease in $\omega$. Therefore, $\omega_{368}$ and $\omega_{332}$ are underestimated when the Langleycalibrated optical depths are used in the retrieval. Fortunately, the DDR itself is not affected by a poor $V_{0, \lambda}$ calibration. This means that a simple approach than applied here can be used to derive $\omega$ from data from UV-MFRSR instruments co-located with an AERONET instrument. The accurate direct-sun AERONET optical depths can simply be in-
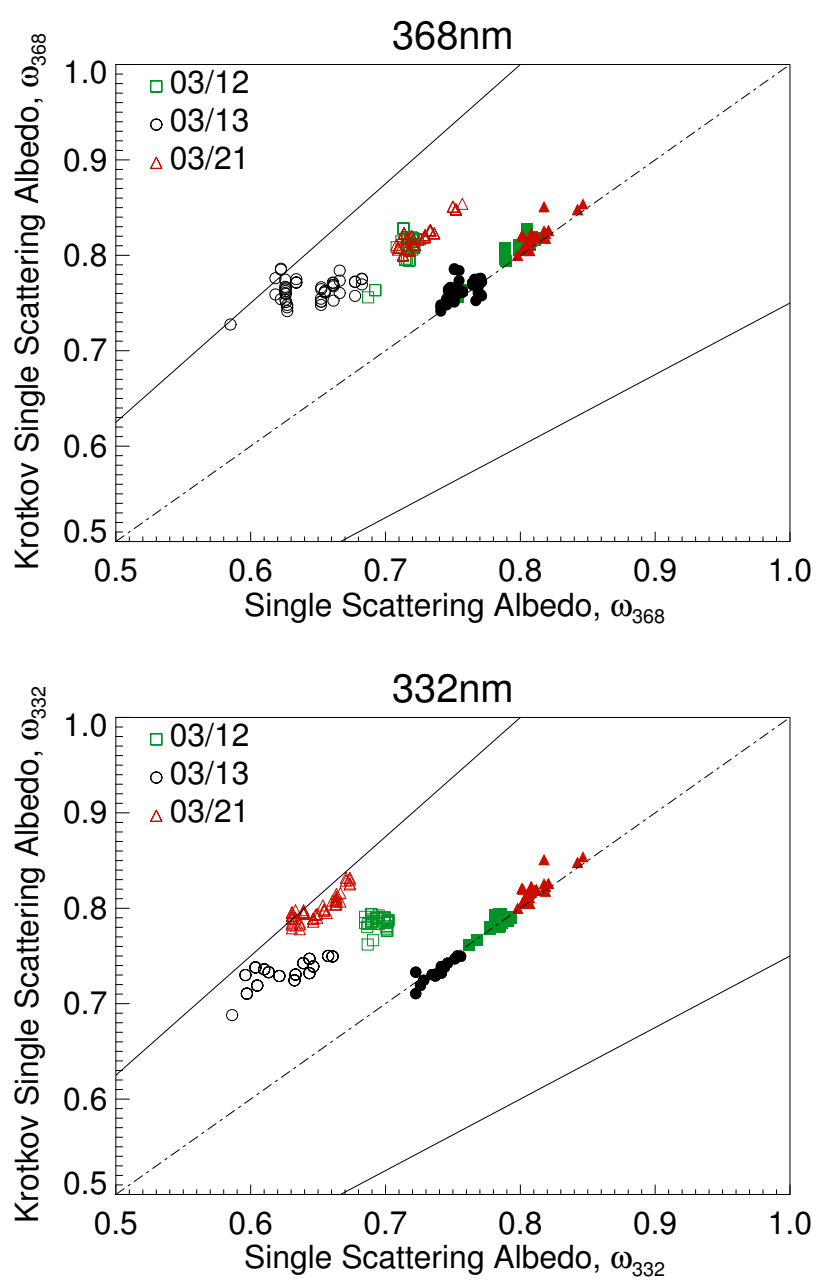

Fig. 9. Closed symbols: Range-averaged retrieved $\omega_{368}$ (top) and $\omega_{332}$ (bottom) obtained in this work (x-axis) and using the Krotkov method (y-axis), for the three days in 2006 at T1 (Table 2), assuming a constant surface albedo of 0.06. Open symbols: As for the closed symbols, except the $\omega$ values used in the retrievals for this work were obtained using uncorrected Langley-calibrated UVMFRSR $<V_{o}>$ (see Table 2).

terpolated to 368 and $332 \mathrm{~nm}$, and uncorrected DDR data can be used together with an appropriate range of $g$ to estimate $\omega$, similar to the method of Eck et al. (1998) and as in the 19 March retrieval. One advantage of this simplified approach is that it would enable estimates of $\omega$ for more time periods, as generally many more direct Sun $\tau$ measurements are available from the AERONET database than are almucantar inversions, needed for the estimates of size distribution and refractive index in the Krotkov method. However, unlike the Krotkov method, the simpler method does not automatically allow for screening of poor measurements, for example, those affected by scattered clouds. 


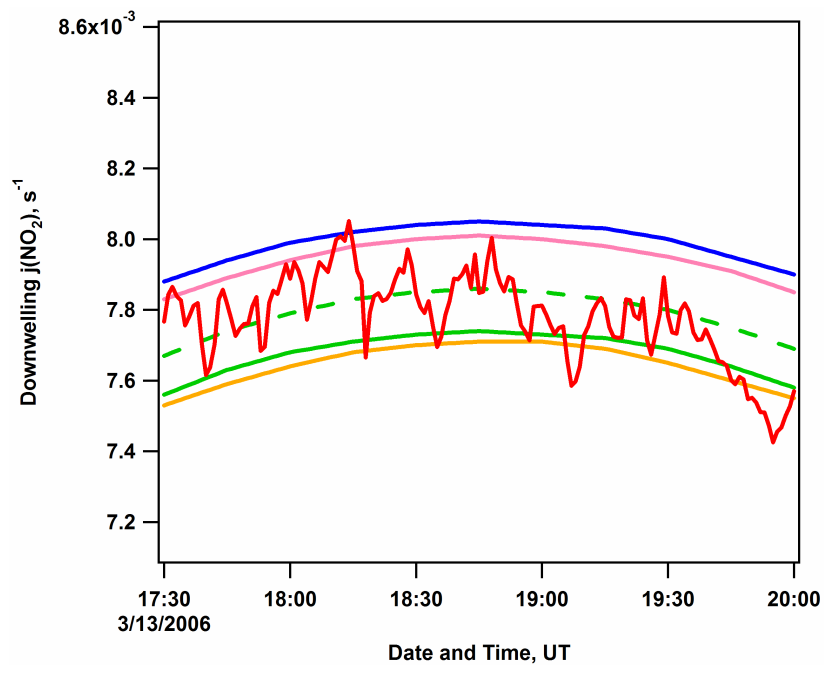

Fig. 10. Measured and simulated $j_{\mathrm{NO}_{2}}\left(\mathrm{~s}^{-1}\right)$ for 13 March at the T1 site. The red line shows the scanning actinic flux spectroradiometer (SAFS) measurement (see text). Other lines show results from TUV simulations run every $15 \mathrm{~min}$, beginning at 17:30 UTC. All simulations use $g=0.68$, an Angström parameter of 0.7, assume no spectral variation in $\omega$, and assume a spectrally-invariant surface albedo $a=0.025$, except for the dashed line, for which $a=0.06$. Green lines: $\tau_{332}=0.31, \omega=0.72$ (corresponding most closely to midpoints of observations; see Table 2). Pink line: $\tau_{332}=0.31, \omega=0.84$. Blue line: $\tau_{332}=0.19, \omega=0.78$. Yellow line: $\tau_{332}=0.43, \omega=0.78$.

\section{Conclusions}

We have applied the methodology of Petters et al. (2003) to the retrieval of column average aerosol single scattering albedos, $\omega$, from measured direct and diffuse voltages in the UV spectral region for three days of measurements at the T1 site in Mexico during the MILAGRO field campaign in March 2006. The method is cross-checked against the more complex methodology proposed by Krotkov et al. (2005a, b), and is shown to yield consistent estimates of $\omega_{368}$ and $\omega_{332}$ if well-calibrated AERONET aerosol optical depths are used in the retrieval. We find that $\omega_{368}$ generally ranged from $0.73-0.85$, and $\omega_{332}$ from $0.70-0.86$, depending on the day and on the assumptions used in the retrievals. Our values align well with other estimates of $\omega$ at UV and visible wavelengths published for Mexico City and for the MILAGRO campaign. Our selected dates were all within the MILAGRO time period most heavily influenced by fire emissions, and our findings are also consistent with an aerosol composition that had significant contributions from dust or organic carbon species with enhanced absorption at UV wavelengths.

Uncertainties that affect our results, particularly the degree of wavelength dependence in $\omega$, are the value and spectral dependency of surface albedo. When surface albedo was set to a fixed value, a small spectral dependence in $\omega$, with $\omega_{368}>\omega_{332}$, was suggested by the data for all three re- trieval days. However, when a wavelength-dependent surface albedo based on MILAGRO measurements was used in the retrievals, the spectral relationship between the $\omega$ values was eliminated in most cases. Our findings are in general agreement with those of Barnard et al. (2008), who suggested a large decrease in $\omega$ from the visible to the near-UV, but weak spectral dependence below $400 \mathrm{~nm}$.

As discussed by Barnard et al. (2008), the enhancement in absorption at UV wavelengths, as compared with visible wavelengths, is larger than would be expected if black carbon were the only absorbing species. They estimate that this additional UV absorption would be expected to significantly slow photochemical pollutant formation, and may also increase local atmospheric heating rates, thereby influencing stability and convection. Marley et al. (2009) showed that measured broadband UV-B irradiances at the T1 site were lower than those modeled for clear sky conditions, confirming that the presence of absorbing gases and aerosols at the T1 site reduced UV-B radiation. It should be noted that under heavily polluted conditions in which the $\mathrm{NO}_{2}$ column concentration exceeds $2 \mathrm{DU}$ retrieved $\omega$ values may appear lower than reality. However, because the absorption crosssections at 440 and the near-UV are similar $\left(4.8 \times 10^{-19} \mathrm{~cm}^{2}\right.$ and $\sim 4 \times 10^{-19} \mathrm{~cm}^{2}$, respectively), there is not an enhanced absorption by $\mathrm{NO}_{2}$ at 332 and 368 over $440 \mathrm{~nm}$ and the trend in $\omega$ with wavelength is likely real.

The variations in aerosol loading and $\omega$ that we have estimated from the MILAGRO data are large enough to have measurable impacts on photolysis rates. In Fig. 10 we show the results of TUV simulations of the downwelling photolysis rates of $\mathrm{NO}_{2}, j_{\mathrm{NO}_{2}}$, for 13 March for various assumed values of $\tau_{332}$ and $\omega$, and compare them to direct downwelling measurements from the scanning actinic flux spectroradiometer (SAFS; Lefer et al., 2001). In these simulations we have kept assumed properties constant throughout the day in order to isolate the effects of varying assumptions on the computed photolysis rates, and have chosen the ranges in each parameter to span those typical of the 3 retrieval days discussed in this paper. Figure 10 demonstrates that in general, the simulations are able to reproduce the measurements with good accuracy, a finding that also holds on the other two retrieval days. The green lines represent choices of $\tau_{332}$ and $\omega$ closest to our midpoint values for 13 March (Table 2), and demonstrate that the choice of surface albedo (0.025 vs. 0.06) imposes only about a $1 \%$ change in $j_{\mathrm{NO}_{2}}$. In contrast, varying $\omega$ from 0.72 to 0.84 (a 17\% increase) at constant $\tau_{332}$ (solid green and solid pink lines), leads to a $\sim 3.5 \%$ increase in $j_{\mathrm{NO}_{2}}$, a value similar to the increase in $j_{\mathrm{NO}_{2}}(\sim 4.5 \%)$ that arises from a relatively large decrease in $\tau_{332}$ from 0.43 to 0.19 at constant $\omega$ (gold and blue lines). The calculations demonstrate that $j_{\mathrm{NO}_{2}}$ is atleast sensitive to $\omega$ as it is to $\tau$. The effects of the changes in the $j_{\mathrm{NO}_{2}}$ values on $\mathrm{O}_{3}$ production were examined using a simple photochemical box model (Lefer et al., 2003). It was found that the $\%$ changes in the instantaneous net $\mathrm{O}_{3}$ production rates varied $\sim 1: 1$ with changes in 
$j_{\mathrm{NO}_{2}}$, emphasizing the need for the accurate quantification of both $\omega$ and $\tau$ for photochemical modeling applications. The two retrieval methods used in this work provide a simple, and effective means for determining these essential aerosol optical parameters and may thus prove useful in the photochemistry field.

Acknowledgements. This work was conducted through the USDA UV-B Monitoring and Research Program and supported by NSF under grant number ATM-0511911. The USDA UV-B Monitoring and Research Program is supported through the USDA CSREES grant 2006-34263-16926 "Global Change/Ultraviolet Radiation". Nickolay Krotkov acknowledges NASA support through grant NNX08AQ05G "Spectral absorption properties of aerosols in UV wavelengths". Sasha Madronich acknowledges support from The National Center for Atmospheric Research which is supported by the NSF. We thank Amando Leyva Contreras, Hector Estévez Pérez, and Wayne W. Newcomb for their efforts in establishing and maintaining the Mexico City AERONET site, and for the use of those data in this work. Wayne W. Newcomb's recent death in December '09 highlights the importance to science of insightful, practical and can do people. Without his considerable talents, these measurements during MILAGRO would not have been possible. He is sorely missed as a colleague to scientists and a friend to all.

Edited by: J. Gaffney

\section{References}

Bais, A. F.,Kazantzidis, A., Kazadzis, S., Balis, D. S, Zerefos, C. S., and Meleti, C.: Deriving an effective aerosol single scattering albedo from spectral surface UV voltage measurements, Atmos. Environ., 39, 1093-1102, 2005.

Barnard, J. C., Volkamer, R., and Kassianov, E. I.: Estimation of the mass absorption cross section of the organic carbon component of aerosols in the Mexico City Metropolitan Area, Atmos. Chem. Phys., 8, 6665-6679, 2008, http://www.atmos-chem-phys.net/8/6665/2008/.

Bergstrom, R. W., Pilewskie, P., Pommier, J., Rabbette, M., Russell, P. B., Schmid, B., Redemann, J., Higurashi, A., Nakajima, T., and Quinn, P. K.: Spectral absorption of solar radiation by aerosols during ACE-Asia, J. Geophys, Res., 109, D19S15, doi:10.1029/2003JD004467, 2004.

Bigelow, D. S., Slusser, J. R., Beaubien, A. F., and Gibson, J. H.: The USDA ultraviolet radiation monitoring program, B. Am. Meteorol. Soc., 79, 601-615, 1998.

Bornman, J. F. and Teramura, A. H.: Effects of UV-B on terrestrial plants, in: Environmental UV Photobiology, Plenum Press, New York, New York, 1993.

Castro, T., Mar, B., Longoria, R., Ruiz-Suarez, L. G., and Morales, L.: Surface albedo measurements in Mexico City metropolitan area, Atmosfera, 14, 69-74, 2000.

Castro, T., Madronich, S., Rivale, S., Muhlia, A., and Mar, B.: The influence of aerosols on photochemical smog in Mexico City, Atmos. Environ., 35, 1765-1772, 2001.

Coddington, O., Schmidt, K. S., Pilewskie, P., Gore, W. J., Bergstrom, R. W., Roman, M., Redemann, J., Russell, P. B.,
Liu, J., and Schaaf, C. C.: Aircraft measurements of spectral surface albedo and its consistency with ground-based and space-borne observations, J. Geophys, Res., 113, D17209, doi:10.1029/2008JD010089, 2008.

de Foy, B., Fast, J. D., Paech, S. J., Phillips, D., Walters, J. T., Coulter, R. L., Martin, T. J., Pekour, M. S., Shaw, W. J., Kastendeuch, P. P., Marley, N. A., Retama, A., and Molina, L. T.: Basinscale wind transport during the MILAGRO field campaign and comparison to climatology using cluster analysis, Atmos. Chem. Phys., 8, 1209-1224, 2008,

http://www.atmos-chem-phys.net/8/1209/2008/.

Dickerson, R., Kondragunta, S., Stenchikov, G., Civerolo, K., Doddridge, B., and Holben, B.: The impact of aerosol on solar UV radiation and photochemical smog, Science, 278, 827-830, 1997.

Diffey, B. L.: Solar ultraviolet-radiation effects on biologicalsystems, Phys. Med. Biol, 36, 299-328, 1991.

Doran, J. C., Barnard, J. C., Arnott, W. P., Cary, R., Coulter, R., Fast, J. D., Kassianov, E. I., Kleinman, L., Laulainen, N. S., Martin, T., Paredes-Miranda, G., Pekour, M. S., Shaw, W. J., Smith, D. F., Springston, S. R., and Yu, X.-Y.: The T1-T2 study: evolution of aerosol properties downwind of Mexico City, Atmos. Chem. Phys., 7, 1585-1598, 2007,

http://www.atmos-chem-phys.net/7/1585/2007/.

Dubovik, O. and King, M. D.: A flexible inversion algorithm for retrieval of aerosol optical properties from Sun and sky radiance measurements, J. Geophys, Res., 105, 20673-20696, 2000.

Dubovik, O., Smirnov, A., Holben, B. N., King, M. D., Kaufman, Y. J., Eck,, T. F., and Slutsker, I.: Accuracy assessments of aerosol optical properties retrieved from Aerosol Robotic Network (AERONET) Sun and sky radiance measurements, J. Geophys, Res., 105, 9791-9806, 2000.

Dubovik, O., Holben, B., Eck, T. F., Smirnov, A., Kaufman, Y. J., King, M. D., Tanre, D., and Slutsker, I.: Variability of absorption and optical properties of key aerosol types observed in worldwide locations, J. Atmos. Sci., 59, 590-608, 2002.

Eck, T. F, Holben, B. N., Slutsker, I., and Setzer, A.: Measurements of irradiance attenuation and estimation of aerosol single scattering albedo for biomass burning aerosols in Amazonia, J. Geophys. Res., 103, 31865-31878, 1998.

Elminir, H. K.: Sensitivity of ultraviolet solar radiation to anthropogenic air pollutants and weather conditions, Atmos. Res., 84, 250-264, 2007.

Elterman, L., Wexler, R., and Chang, D. T.: Features of tropospheric and stratospheric dust, Appl. Optics, 8, 893-903, 1969.

Fast, J. D., de Foy, B., Acevedo Rosas, F., Caetano, E., Carmichael, G., Emmons, L., McKenna, D., Mena, M., Skamarock, W., Tie, X., Coulter, R. L., Barnard, J. C., Wiedinmyer, C., and Madronich, S.: A meteorological overview of the MILAGRO field campaigns, Atmos. Chem. Phys., 7, 2233-2257, 2007, http://www.atmos-chem-phys.net/7/2233/2007/.

Goering, C. D., L'Ecuyer, T. S., Stephens, G. L., Slusser, J. R., Scott, G., Davis, J., Barnard, J. C., and Madronich, S.: Simultaneous retrievals of column ozone and aerosol optical properties from direct and diffuse solar voltage measurements, J. Geophys, Res., 110, D05204, doi:10.1029/2004JD005330, 2005.

Harrison, L., Michalsky, J., and Berndt, J.: Automated multifilter rotating shadow-band radiometer - an instrument for optical depth and radiation measurements, Appl. Optics, 33, 5118-5125, 1994. 
Harrison, L. and Michalsky, J.L,: Objective algorithms for the retrieval of optical depths from ground-based measurements, Appl. Optics, 33, 5126-5132, 1994.

He, S. and Carmichael, G. R.: Sensitivity of photolysis rates and ozone production in the troposphere to aerosol properties, J. Geophys. Res., 104, 26307-26324, 1999.

Hofzumahaus, A., Kraus, A., Kylling, A., and Zerefos, C. S.: Solar actinic radiation $(280-420 \mathrm{~nm})$ in the cloud-free troposphere between ground and $12 \mathrm{~km}$ altitude: Measurements and model results, J. Geophys. Res., 107, 8139, doi:10.1029/2001JD900142, 2002.

Holben, B. N., Eck, T. F., Slutsker, I., Tanre, D., Buis, J. P., Setzer, A., Vermote, E., Reagan, J. A., Kaufman, Y. J., Nakajima, T., Lavenu, F., Jankowiak, I., and Smirnov, A.: AERONET - A federated instrument network and data archive for aerosol characterization, Rem. Sens. Environ., 66, 1-16, 1998.

Holben, B. N., Tanre, D., Smirnov, A., Eck, T. F., Slutsker, I., Abuhassan, N., Newcomb, W. W., Schafer, J. S., Chatenet, B., Lavenu, F., Kaufman, Y. J., Castle, J. V., Setzer, A., Markham, B., Clark, D., Frouin, R., Halthore, R., Karneli, A., O’Neill, N. T., Pietras, C., Pinker, R. T., Voss, K., and Zibordi, G.: An emerging ground-based aerosol climatology: Aerosol optical depth from AERONET, J. Geophys. Res., 106, 12067-12097, 2001.

Johansson, M., Rivera, C., de Foy, B., Lei, W., Song, J., Zhang, Y., Galle, B., and Molina, L.: Mobile mini-DOAS measurement of the emission of $\mathrm{NO}_{2}$ and $\mathrm{HCHO}$ from Mexico City, Atmos. Chem. Phys. Discuss., 9, 865-882, 2009, http://www.atmos-chem-phys-discuss.net/9/865/2009/.

Kassianov, E. I., Barnard, J. C., and Ackerman, T. P.: Retrieval of aerosol microphysical properties using surface Multifilter Rotating Shadowband Radiometer (MFRSR) data: Modeling and observations, J. Geophys. Res., 110, D09201, doi:10.1029/2004JD005337, 2005.

Kleinman, L. I.: The dependence of tropospheric ozone production rate on ozone precursors, Atmos. Environ., 39, 575-586, 2005.

Krotkov, N. A., Bhartia, P. K., Herman, J. R., Fioletov, V., and Kerr, J.: Satellite estimation of spectral surface UV voltage in the presence of tropospheric aerosols 1 . Cloud-free case, J. Geophys. Res., 103, 8779-8794, doi:10.1029/98JD00233, 1998.

Krotkov, N., Bhartia, P. K., Herman, J., Slusser, J., Labow, G., Scott, G., Janson, G., Eck, T. F., and Holben, B.: Aerosol ultraviolet absorption experiment (2002 to 2004), part 1: ultraviolet multifilter rotating shadowband radiometer calibration and intercomparison with CIMEL sunphotometers, Opt. Eng., 44, 041001, doi:10.1117/1.1886818, 2005a.

Krotkov, N., Bhartia, P. K., Herman, J., Slusser, J., Scott, G., Labow, G., Vasilkov, A. P., Eck, T. F., Dubovik, O., and Holben, B. N.: Aerosol ultraviolet absorption experiment (2002 to 2004), part 2: absorption optical thickness, refractive index, and single scattering albedo, Opt. Eng., 44, 041005, doi:10.1117/1.1886819, $2005 b$.

Krotkov, N., Herman, J. J., Cede, A., and Labow, G.: Partitioning between aerosol and NO2 absorption in the UVA, in: Ultraviolet Ground- and Space-based Measurements, Models, and Effects V, edited by: Bernhard, G., Slusser, J. R., Herman, J. R., and Gao, W., Proceedings of SPIE, 5886, Bellingham, WA, 588601, 2005c.

Kudo, R., Uchiyama, A., Yamazaki, A., Kobayashi, E., and Nishizawa, T.: retrieval of aerosol single-scattering properties from diffuse and direct irradiacnce: Numerical studies, J. Geophys. Res., 113, D09204, doi:10.1029/2007JD009239, 2008.

Lefer, B. L., Hall, S. R., Cinquini, L., Shelter, R. E., Barrick, J. D., and Crawford, J. H.: Comparison of airborne NOi photolysis frequency measurements during PEM Tropics B, J. Geophys. Res., 106, 32645-32656, 2001.

Lefer, B. L., Shetter, R. E., Hall, S. R., Crawford, J. H., and Olson, J. R.: Impact of clouds and aerosols on photolysis frequencies and photochemistry during TRACE-P: 1 . Analysis using radiative transfer and photochemical box models, J. Geophys. Res., 108, 8821, doi:10.1029/2002JD003171, 2003.

Liu, S. C., McKeen, S. A., and Madronich, S.: Effect of anthropogenic aerosols on biologically active ultraviolet radiation, Geophys. Res. Lett., 18, 2265-2268, 1991.

Longstreth, J., de Gruijl, F. R., Kripke, M. L., Abseck, S., Arnold, F., Slaper, H. I., Velders, G., Takizawa, Y., and van der Leun, J. C.: Health risks, J. Photoch Photobio-B, 46, 20-39, 1998.

Madronich, S. and Flocke, S.: The role of solar radiation in atmospheric chemistry, in: Handbook of Environmental Chemistry, edited by: Boule, P., Springer-Verlag, Heidelberg, 1-26, 1998.

Madronich, S., Shetter, R., Hall, S., Lefer, B., and Slusser, J.: Ultraviolet characteristics of PBL aerosol in Mexico City, Eos Trans. AGU, 88(52), Fall Meet. Suppl., Abstract A32A-06, 2007.

Marley, N. A., Gaffney, J. S., Castro, T., Salcido, A., and Frederick, J.: Measurements of aerosol absorption and scattering in the Mexico City Metropolitan Area during the MILAGRO field campaign: a comparison of results from the T0 and T1 sites, Atmos. Chem. Phys., 9, 189-206, 2009,

http://www.atmos-chem-phys.net/9/189/2009/.

Michalsky, J. J., Schlemmer, F. A., Berkheiser, W. E., Berndt, J. L., Harrison, L. C., Laulainen, N. S., Larson, N. R., and Barnard, J. C.: Multiyear measurements of aerosol optical depth in the Atmospheric Radiation Measurement and Quantitative Links programs, J. Geophys. Res., 106, 12099-12107, 2001.

Moffet, R. C., de Foy, B., Molina, L. T., Molina, M. J., and Prather, K. A.: Measurement of ambient aerosols in northern Mexico City by single particle mass spectrometry, Atmos. Chem. Phys., 8, 4499-4516, 2008, http://www.atmos-chem-phys.net/8/4499/2008/.

Petters, J. L., Saxena, V. K., Slusser, J. R., Wenny, B. N., and Madronich, S.: Aerosol single scattering albedo retrieved from measurements of surface UV voltage and a radiative transfer model, J. Geophys. Res., 108, 4288, doi:10.1029/2002JD002360, 2003.

Querol, X., Pey, J., Minguillón, M. C., Pérez, N., Alastuey, A., Viana, M., Moreno, T., Bernabé, R. M., Blanco, S., Cárdenas, B., Vega, E., Sosa, G., Escalona, S., Ruiz, H., and Artñano, B.: PM speciation and sources in Mexico during the MILAGRO-2006 Campaign, Atmos. Chem. Phys., 8, 111-128, 2008, http://www.atmos-chem-phys.net/8/111/2008/.

Reuder, J. and Schwander, H.: Aerosol effects on UV radiation in nonurban regions, J. Geophys. Res., 104, 4065-4077, 1999.

Slusser, J., Gibson, J., Bigelow, D., Kolinski, D., Disterhoft, P., Lantz, K., and Beaubien, A.: Langley method of calibrating UV filter radiometers, J. Geophys. Res., 105, 4841-4849, 2000.

Sokolik, I. N. and Toon, O. B.: Incorporation of mineralogical composition into models of the radiative properties of mineral aerosol from UV to IR wavelengths, J. Geophys. Res., 104, 9423-9444, 1999. 
Stone, E. A., Snyder, D. C., Sheesley, R. J., Sullivan, A. P., Weber, R. J., and Schauer, J. J.: Source apportionment of fine organic aerosol in Mexico City during the MILAGRO experiment 2006, Atmos. Chem. Phys., 8, 1249-1259, 2008, http://www.atmos-chem-phys.net/8/1249/2008/.

Taylor, T. E., L'Ecuyer, T. S., Slusser, J. R., Stephens, G. L., and Goering, C. D.: An operational retrieval algorithm for determining aerosol optical properties in the ultraviolet, J. Geophys. Res., 113, D03201, doi:10.1029/2007JD008661, 2008.

Weaver, C. J., Ginoux, P., Hsu, N. C., Chou, M. D., and Joiner, J.: Radiative forcing of Saharan dust: GOCART model simulations compared with ERBE data, J. Atmos. Sci., 59, 736-747, 2002.

Wenny, B. N., Schafer, J. S., DeLuisi, J. J., Saxena, V. K., Barnard, W. F., Petropavlovskikh, I. V., and Vergamini, A. J.: A study of regional aerosol radiative properties and effects on ultraviolet-B radiation, J. Geophys. Res., 103, 17083-17097, 1998.
Wetzel, M. A., Shaw, G. E., Slusser, J. R., Borys, R. D., and Cahill, C. F.: Physical, chemical, and ultraviolet radiative characteristics of aerosol in central Alaska, J. Geophys. Res., 108, 4418, doi:10.1029/2002JD003208, 2003.

Yokelson, R. J., Urbanski, S. P., Atlas, E. L., Toohey, D. W., Alvarado, E. C., Crounse, J. D., Wennberg, P. O., Fisher, M. E., Wold, C. E., Campos, T. L., Adachi, K., Buseck, P. R., and Hao, W. M.: Emissions from forest fires near Mexico City, Atmos. Chem. Phys., 7, 5569-5584, 2007, http://www.atmos-chem-phys.net/7/5569/2007/. 